\title{
沿岸砂州の中・長期変動特性および その影響要因
}

\author{
栗山 善昭 1 伊東 啓勝 2 柳嶋 慎一 3 \\ 1正会員（独）港湾空港技術研究所 海洋 - 水工部漂砂研究室長（†239-0826 神奈川県横須賀市長瀬3-1-1） \\ E-mail: kuriyama@pari.go.jp \\ 2正会員（株）エコー 沿岸デザイン本部調査解析部主任（テ110-0014 東京都台東区北上野2-6-4） \\ 3正会員（独）港湾空港技術研究所 海洋 - 水工部主任研究官（†239-0826 神奈川県横須賀市長瀬3-1-1）
}

\begin{abstract}
茨城県の波崎海洋研究施設において15年間（1987年～2001年）にわたりほぼ毎日取得した断面データを 経験的複素固有関数法（CEOF解析）を用いて解析した. バーの沖向き移動速度に比例するバーの位相の 変動周波数は，1994年以前は0.8～1.3 cycle/year（周期0.7〜 1.25年）であったものの，1994年以降，次第に 小さくなり，1996年末には0.1 cycle/year（周期10年）にまで低下した。 バーの振幅も，長期的にはバーの 移動速度と同様の時間変動を示しており，その值は，観測期間前半（1994年以前）よりも後半（1995年以 降）の方が小さかった。このようなバーの長期変動には，外的要因である沖波エネルギーフラックスが影 響していただけでなく，バーの振幅に関する負のフィードバック機構も関与していた.
\end{abstract}

Key Words : longshore bar, offshore migration, CEOF, field measurement, long-term data

\section{1. はじめに}

沿岸砂州（以下，バー）は汀線近傍の地形変化や生態 系に影響を与えると考えられ ${ }^{1)}$, 2)，海岸管理上，バーの 変動特性の把握は重要である，そのため，長期にわたつ て収集された深浅データやビデオ画像データを基にした バーの変動特性の検討が世界各地で行われている. 茨城 県の波崎海岸では 1 年周期のバーの沖向き移動が観測さ れており 3), 4)，アメリカ東海岸では 4 年周期 5), 6), オラ ンダでは 6〜20 年周期 7), 8), ニュージーランドでは 2〜5 年周期 9)のバーの沖向き移動が観測されている.さらに, ポーランドにおいても 12 年以上のバーの変動が観測さ れている ${ }^{10)}$. これらのバーの沖向き移動に関して,

Shand $5^{11) や ~ R u e s s i n k ~} 5^{12)}$ は各海岸の平均的なバーの移 動周期やバーの波長などの特性と波, 流れ, 風, 海底勾 配などの外力との関係を検討している.

バーの 1〜2 週間程度の短期の移動特性と外力との関 係に関しては，アメリカ東海岸で取得されたデータを基 にしたいくつかの研究がある. Sallenger \& Howd ${ }^{13}$ は地形 と波浪に関する 2 回の約 1 週間の現地観測結果を基に, バーの移動に及ぼす砕波の影響が小さいことを示した.

Lippmann \& Holman ${ }^{14)}$ は 2 年間のビデオ画像データを基に バーの移動と沖波波高との関係を検討し，波高が大きく
なるとバーは沖向き移動することを示した．Plant ら ${ }^{15)}$ は， 16 年間の深浅データを基にバー頂部の移動と沖波波高 との関係を検討し，沖波波高が大きいほどバ一頂部は沖 へ移動し，平衡状態に近づくことを示した.さらに Plant ら ${ }^{16}$ は同じ 16 年間の深浅データを基にバーの移動, 発達・減衰とバ一頂部の波高水深比との関係を検討し, 波高水深比が大きい場合にはバーは沖向きに移動し, 波 高水深比が小さい場合にはバーは岸向きに移動しつつ減 衰することを示した. Larson ら ${ }^{177}$ は 11 年間の断面デー 夕を基に断面形状と砕波率との関係を正準相関分析を用 いて検討し, 波高が大きいほど沖での砕波率が大きくな り，底質が沖に堆積する，すなわち，沖にバーが移動す ることを示した.

バーの短期の岸向き移動に関しては, Greenwood \&

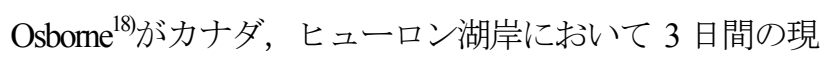
地観測を行い，バーの岸向き移動は時化減衰期において ボアによって生じた岸向きの流速の skewness に関係して いることを示した. Miller ら ${ }^{19}$ は，アメリカ東海岸で取 得した約 10 日間の現地データを解析し, 戻り流れの速 度が小さく, 波の非線形性が大きいときにバーが岸向き に移動することを示した，さらに， Elgar ら 201は，アメ リカ東海岸における約 2 ケ月の現地観測結果と波浪変形 のシミュレーション結果を基に，バーの岸向き移動には 
加速度の skewness が影響していることを示した。

栗山ら ${ }^{21)}$, Kuriyama \& Yamada ${ }^{22)}$ は茨城県波崎海岸にお ける砕波帯内の地形と波浪に関する 2 週間の現地データ を解析し，バーの移動に及ぼす長周期波の影響が小さい ことを示した.

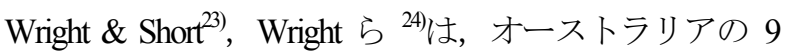
海岸の 7 年間の現地データを基にバー頂部の岸沖方向位 置やその沿岸方向分布で規定される海浜の状態（ビーチ ステージ）の推移を推定するパラメーターを提案し，砂 村 ${ }^{25)}$ は既往の研究成果を参照してビーチステージの推移 を推定する別のパラメーターを提案している. Larson \& Kraus $^{20}$ はアメリカ東海岸における 9 年間の現地データを 基にバーの移動方向を推定するパラメーターを提案して おり, Sunamura \& Takeda ${ }^{27}$ は, 日本, アメリカ, オース トラリアにおけるバー移動時のデータを基にして別のパ ラメーターを提案している。ささらに，栗山 ${ }^{28)}$ は，茨城県 波崎海岸における 2 ケ月の現地データを基に，砂村のパ ラメーター ${ }^{25}$ にバー頂部の砕波率を加えたバーの移動方 向推定の新たな手法を提案している.

バーの移動を再現するモデルに関しては，Thornton $ら^{29)}$ と Gallagher $~^{30)}$ が， Bailardの漂砂量式 ${ }^{31)}$ にアメリカ 東海岸で取得された流速の現地観測值を代入して，それ ぞれ約 10 日間および約 2 ケ月間のバー型海岸の地形変 化を計算し, Bailard の漂砂量式は時化時のバーの沖向き 移動を比較的精度良く再現できるものの，静穏時のバー の岸向き移動の再現性の精度は悪いことを明らかにした。 その後, Hoefel \& Elgar ${ }^{32}$ は前述の Bailard の漂砂量式に流 速の加速度項を加えることにより，バーの岸向き移動の 再現精度を向上させた. Plant ら ${ }^{15}$ は，16 年間の現地デ 一タから求めたバ一頂部の移動特性と沖波波高との関係 を基に，沖波波高からバーの頂部位置を推定する簡易モ デルを作成し，8 年間のバーの頂部位置に関して推定值 と実測值とを比較している.

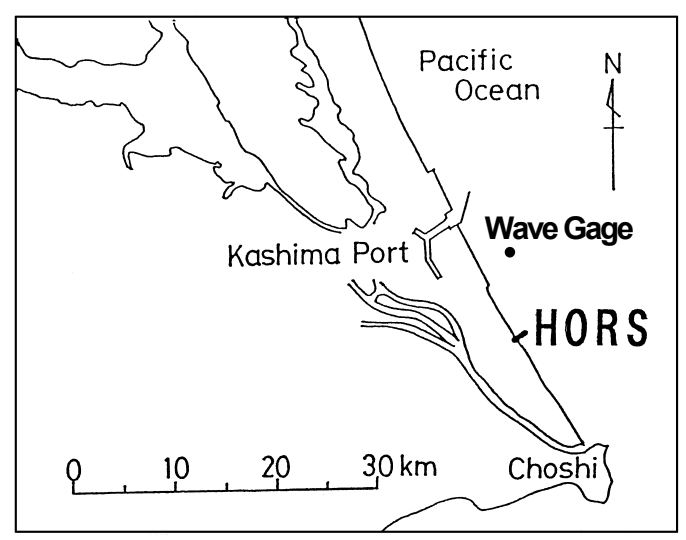

図-1 波崎海洋研究施設の位置
以上のように，時間平均されたバーの移動特性に関す る研究あるいは 1 2 週間程度の短期的なバーの移動特 性に関する研究は数多く存在する. しかしながら, 海岸 管理上重要となる数ヶ月（中期）～数年程度（長期）に おけるバーの移動速度や大きさの変動特性を示した研究 としては前述の Plant ら ${ }^{15}$ の研究が見られる程度でその 数は極めて少なく, その実態は依然として不明であり, さらに，バーの中・長期の移動特性と外力との関係に関 しても知見はほとんど得られていない.

本研究では，茨城県鹿島灘に面する波崎海洋研究施設 で 15 年間ほぼ毎日取得した断面データを基にバーの移 動速度とバーの大きさの中・長期変動特性を検討すると ともに，それらの特性と外力である波の変動特性および バーの発達に関するフィードバック機構との関係を調べ ることによりバーの中・長期変動特性の影響要因を検討 する.

\section{2. 現地データの概要}

茨城県の波崎海岸に位置する波崎海洋研究施設 (Hazaki Oceanographical Research Station, 以下 HORS, 図1) では，長さ約 $400 \mathrm{~m}$ の観測栈橋に沿って，休日を除 く 1 日 1 回，5m 間隔で断面を測定している. 陸上部の 断面はレベルとスタッフを用いて測量し, 海域部は栈橋 上から重さ約 $5 \mathrm{~kg}$ のレッドを降ろして測量する. 本研究 では，1987 年 1 月〜2001 年 12 月までに観測された断面 データを使用した。図-2 は観測期間中の平均断面と標 準偏差とを示したものである. 岸沖方向距離 $180 \mathrm{~m}$ $380 \mathrm{~m}$ の範囲ではバーが発生, 移動, 消滅するため標準 偏差，すなわち地形変動量が大きくなっている. なお， 以下では，観測栈橋上の位置を図-2 の座標を基に示し， 例えば岸沖方向距離 $190 \mathrm{~m}$ の観測地点名は P190m とする.

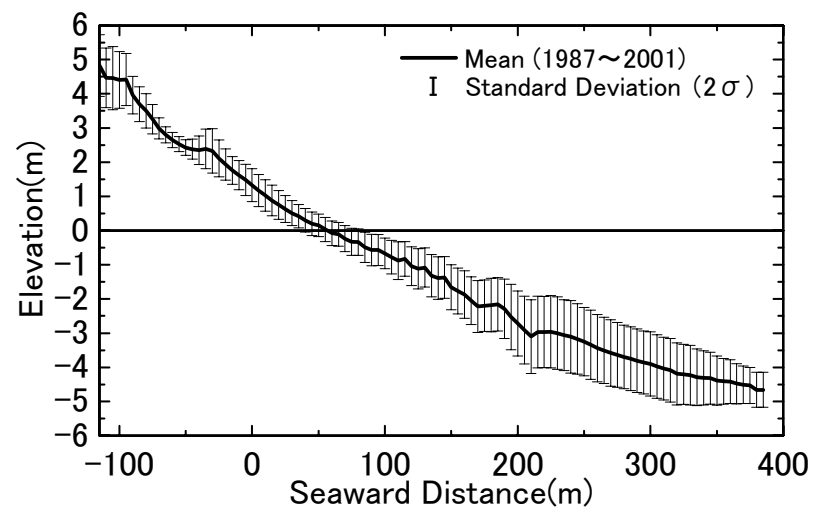

図-2 平均断面（D.L.基準）と標準偏差. 太い実線は平均断面, 細い実線は標準偏差の2倍を示す。 
HORS 周辺地形の 3 次元性に関しては, 栗山 ${ }^{3)}$ HORS をはさむ沿岸方向 $600 \mathrm{~m}$, 岸沖方向 $700 \mathrm{~m}$ の範囲に おいて 1986年〜1998 年に行われた 17 回の深浅測量デー タを解析し，その結果，HORS 周辺の地形は沿岸方向に ほぼ一様であり，HORS で観測された断面はバーの岸沖 移動の解析に使用できるとの結論を得ている.

沖波波高および周期は，鹿島港沖の水深約 $23 \mathrm{~m}$ の地 点（図-1）に設置された超音波式波高計により 2 時間毎 に観測されている。

\section{3. バーの中・長期変動特性}

平均断面（図-2）からの変化量の時空間分布を図-3に 示す. P150m 地点より沖の領域では，解析期間前半の 1993 年以前ではバーあるいは深みが 1 年周期で沖へ移動 していたのに対して，1996 年以降では，バーが P200m
地点から P300m 地点にとどまっている期間が長くその 周期が約 2 年弱になっている様子がうかがえる.

続いて，バーの頂部位置に注目し，その時系列を図-4 に示す．本研究では，栗山 ${ }^{3)}$ と同様にバ一頂部および卜 ラフの位置は，それぞれ断面における極大值および極小 值の位置と定義し，バー頂部とそれより岸側のトラフで の水深差で定義されるバーの比高が $50 \mathrm{~cm}$ 以下のバーは 解析から外した。

波崎海岸では，P180m より沖に常に存在する 1 個のア ウターバーに加えて，時化直後にはインナーバーが汀線 とアウターバーとの間に形成される. アウターバーのバ 一頂部水深の平均值と標準偏差は-2.07m と $0.83 \mathrm{~m}$ であり, バーの比高の平均值と標準偏差は $1.30 \mathrm{~m}$ と $0.58 \mathrm{~m}$ である. アウターバーは，P180m 付近で形成され，徐々に沖に移 動する. HORS で観測された深浅データによると， $\mathrm{P} 450 \mathrm{~m}$ より沖ではバーは観測されていないことから ${ }^{3)}$, バーは栈橋先端の $\mathrm{P} 380 \mathrm{~m}$ に達した直後に消滅すると考 えられる.

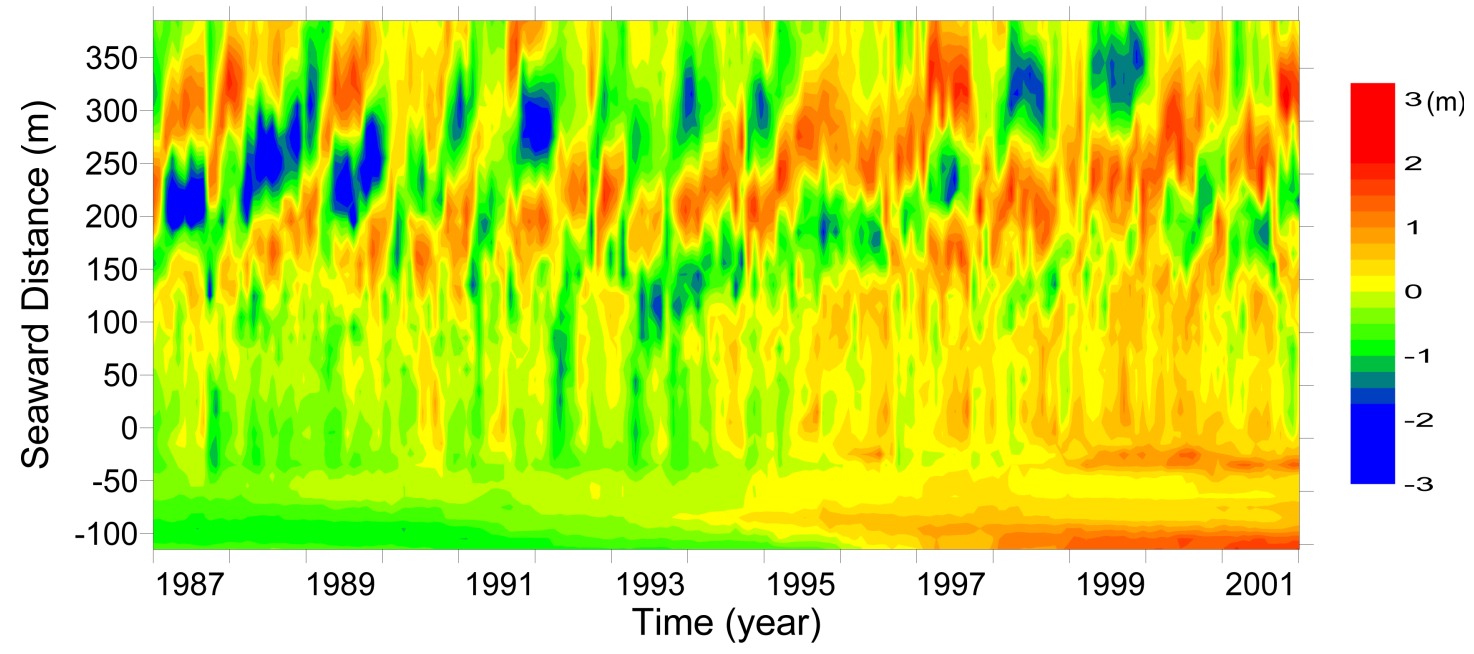

図-3 平均断面からの変化量の時空間分布. 暖色が平均断面よりも上方の領域を，寒色が平均断面よりも下方の領域を 示す.

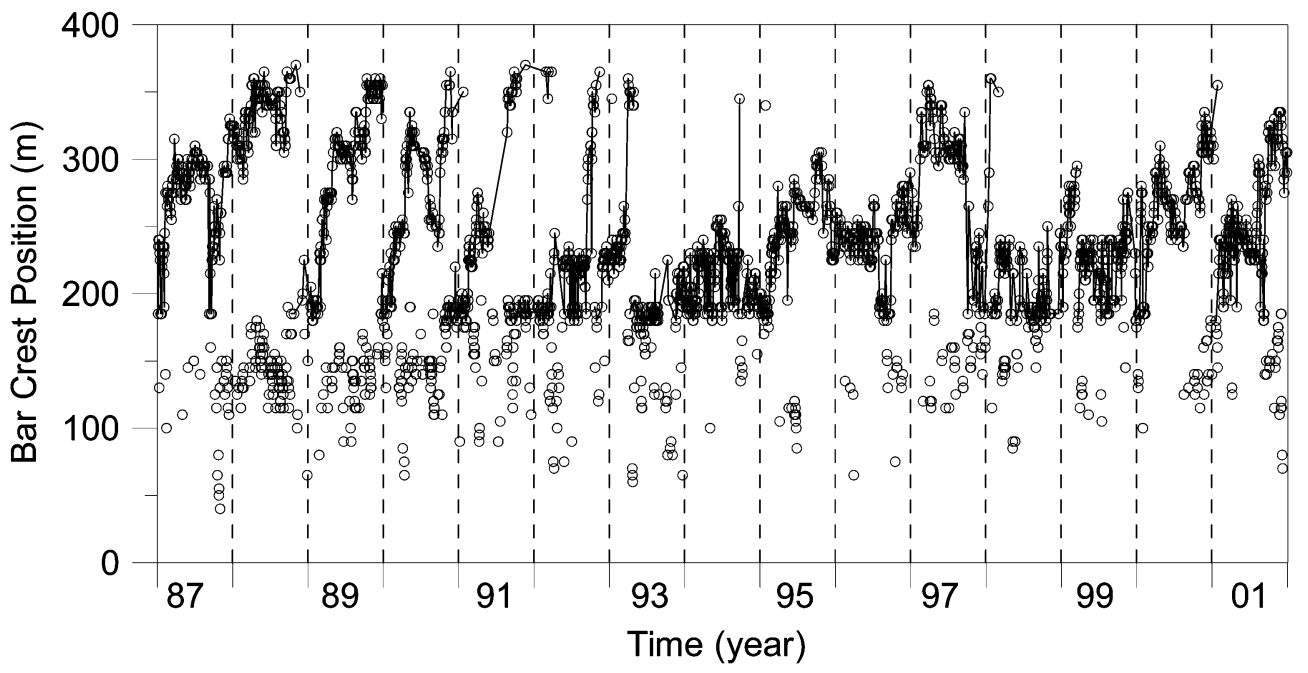

図-4 砂州頂部位置の経時変化 
図-3 からも見て取れるように，バ一頂部は 1993 年以 前はほぼ 1 年周期で沖へ移動しているものの，1996年以 降はその移動速度が遅くなっている（図-4）。

図-3，4 で示された地形変化の周期変動を詳細に検討 するために, P300m 地点における地盤高さの変動に対し て解析期間を 7 年とする STFT (Short Time Fourier Transform）を適用した。 図-5 はその結果の一部を示した もので， $\mathrm{P} 300 \mathrm{~m}$ 地点では，解析期間前半において周期 1.0 年 (周波数 $f=0.0027$ cycle/day) の変動エネルギーが大 きいものの, 次第に周期 1.6 年（周波数 $f=0.0017$ cycle/day）の変動エネルギーが大きくなっており, 図-3, 4 に見られた地形変化の卓越周期の違いがこの解析結果 に明瞭に現れている.

次に, この地形変化の卓越周期の変動を図-3 に示さ れている平均断面からの変動量に対して経験的複素固 有関数法（CEOF 解析）を適用することにより検討した. $\mathrm{CEOF}$ 解析は経験的固有関数法（EOF 解析）が拡張され たもので, 式(1)で定義される複素地盤高さ $Z(x, t)$ を複素 の時間係数と複素の固有関数との積 (式(2)）に分解す るものである（例えば, Liang \& Seymour ${ }^{33)}$, 横木ら ${ }^{34)}$, 北野ら ${ }^{35)}$, Ruessink $~^{36}$, Kuriyama \& Lee ${ }^{37)}$, 内山・栗 山 ${ }^{38)}$ ) .

$$
\begin{gathered}
Z(x, t)=z(x, t)+i \hat{z}(x, t) \\
Z(x, t)=\sum_{n}\left(C_{n r}(t)+i C_{n i}(t)\right)\left(e_{n r}(x)-i e_{n i}(x)\right)
\end{gathered}
$$

ここで, $\hat{z}(x, t)$ は地盤高さ $z(x, t)$ の Hilbert 変換值, $C_{n r}(t)$ と $C_{n i}(t)$ はそれぞれモード $\mathrm{n}$ の複素時間係数の実数部と 虚数部, $e_{n r}(x)$ と $e_{n i}(x)$ はそれぞれモード $\mathrm{n}$ の複素固有関 数の実数部と虚数部である.

モード $\mathrm{n}$ で表される地盤高さの変動 $z_{n}(x, t)$ は固有関数 の共役複素関数を用いて式(3)で再合成される.

$$
z_{n}(x, t)=\operatorname{Re}\left\{\left(C_{n r}(t)+i C_{n i}(t)\right)\left(e_{n r}(x)-i e_{n i}(x)\right)\right\}
$$

式(3)は以下の式に変形することができる（例えば, Ruessink $5^{36)}$ ).

$$
\begin{aligned}
z_{n}(x, t) & =S_{n}(x) R_{n}(t) \cos \left\{\theta_{n}(x)-\psi_{n}(t)\right\}, \\
S_{n}(x) & =\sqrt{e_{n r}(x)^{2}+e_{n i}(x)^{2}}, \\
R_{n}(t) & =\sqrt{C_{n r}(t)^{2}+C_{n i}(t)^{2}}, \\
\theta_{n}(x) & =\arctan \left(e_{n i}(x) / e_{n r}(x)\right), \\
\psi_{n}(t) & =\arctan \left(C_{n i}(t) / C_{n r}(t)\right)
\end{aligned}
$$

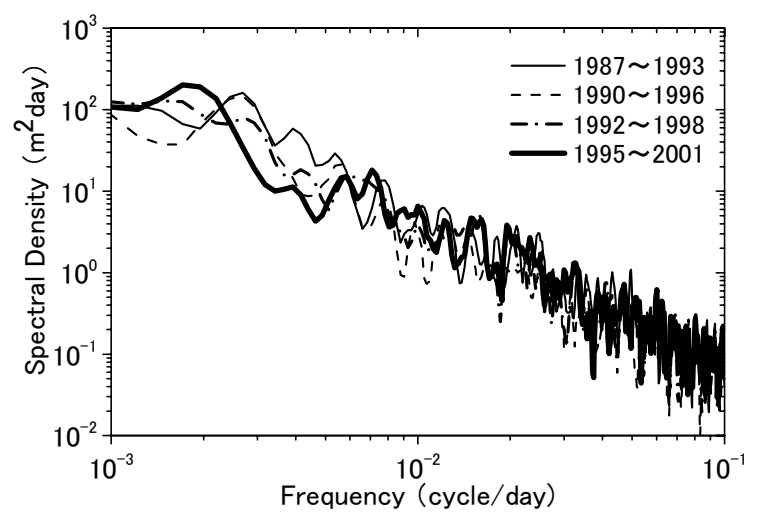

図-5＼cjkstart地盤高さ変動のスペクトル解析結果

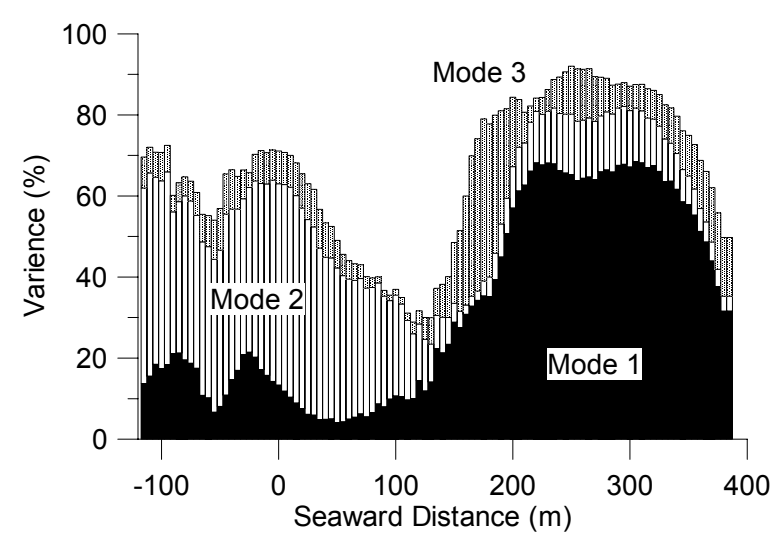

図-6 各観測地点の地盤高さ変動における CEOF 解析のモード $1 \sim 3$ の寄与率

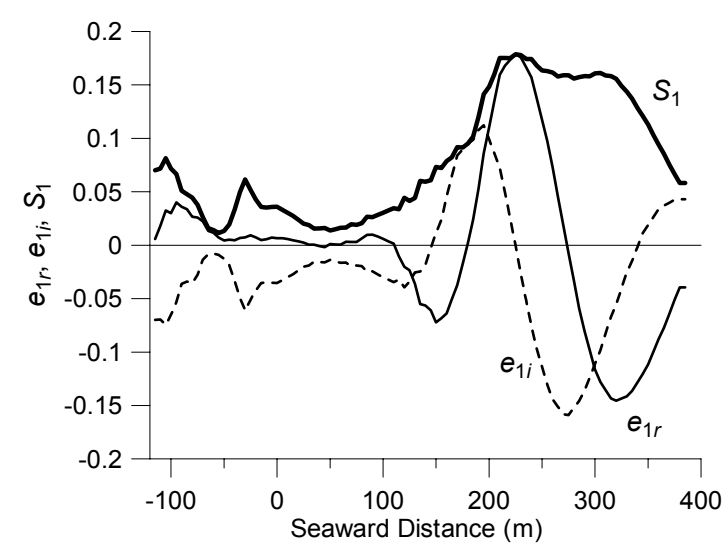

図-7 モード 1 の複素固有関数 $e_{1,}, e_{1 i}$ と振幅 $S_{1}$

ここで，複素時間係数の位相 $\psi_{n}(t)$ は各モードにおける 地形変化の時間位相を表しており， $\psi_{n}(t)$ の変化率が断面 変化の速度となる．また， $R_{n}(t)$ は各モードで表される地 形の平均地形からの偏差の大きさの時間変動を表して いる.

図-6 は各観測地点の地盤高さ変動におけるモード 1 3 の寄与率を示したものであり，図-7 は, CEOF 解析の モード1（寄与率 $49 \%$ ）における複素固有関数 $e_{1 r}, e_{1 i}$ お 
よびその振幅 $S_{1}$ を示したものである. バーの発達する $\mathrm{P} 200 \mathrm{~m}$ 地点 $\sim \mathrm{P} 360 \mathrm{~m}$ 地点では各観測地点の地盤高さ変動 におけるモード 1 の寄与率が $50 \%$ 以上であり，さらに， モード 1 の複素固有関数が $\mathrm{P} 150 \mathrm{~m}$ 地点よりも沖側で大 きくなっていることから，モード1が主としてバーの移 動を表していること, および, その地形変化が本解析 領域における卓越する地形変動であることがわかる.

図-8 はモード 1 の複素時間係数の位相 $\psi_{1}(t) / 2 \pi$ を示し たものである. 複素時間係数の振幅 $R_{1}$ が小さい場合に は $\psi_{1}$ に大きな誤差が含まれる可能性があるので, $R_{1}$ が $1.0 \mathrm{~m}$ 未満の場合の $\psi_{1}$ は， $R_{1}$ が $1.0 \mathrm{~m}$ 以上の場合の $\psi_{1}$ を用 いて線形補間した值に置き換えた。

複素時間係数の位相 $\psi_{1} / 2 \pi$ 変動は図-4に示されるバ 一の頂部位置の変動と似たような傾向を示している. そこで， $\psi_{1} / 2 \pi$ とバーの位置との関係を検討し，図-9に その結果を示した。両者の相関は高く, $\psi_{1} / 2 \pi$ はバー頂 部の位置を良く表している. すなわち， $\psi_{1} / 2 \pi$ の変化率 はバーの位相の変動周波数を表しており, 負の $\psi_{1} / 2 \pi の$ 変化率は沖向きのバ一移動を表していることになる.

続いて, バーの位相の変動周波数 $d\left(\psi_{1} / 2 \pi\right) / d t$ の時間変

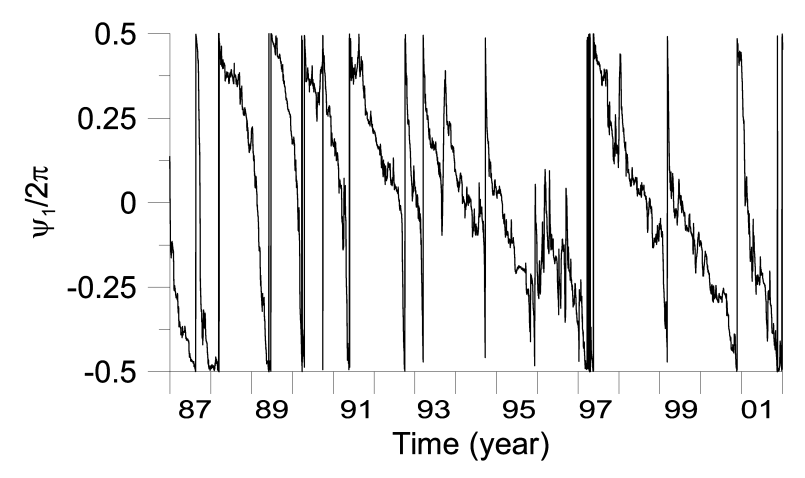

図-8 モード 1 の複素時間係数の位相 $\psi_{1} / 2 \pi$

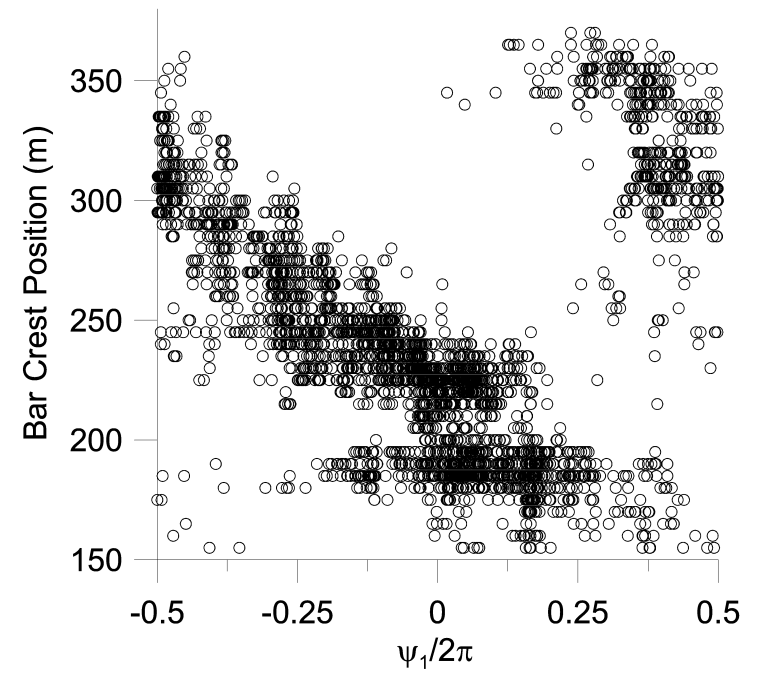

図-9 モード 1 の複素時間係数の位相 $\psi_{1} / 2 \pi$ と砂州頂部位置との 関係
動を検討した. $d\left(\psi_{1} / 2 \pi\right) / d t$ のスペクトル解析結果（図10）は， $d\left(\psi_{1} / 2 \pi\right) d t$ の変動では 40 日（ $f=0.025$ cycle/day $)$, 180 日（6ケ月， $f=0.0055$ cycle/day）および 700 日（1.9年， $f=0.0014$ cycle $/$ day） の周期の変動が卓越していることを 示している. そこで，バーの長周期変動を検討するた めに $d\left(\psi_{1} / 2 \pi\right) / d t$ の 150 日以上の長周期成分および 1000 日 以上の長周期成分を再合成して図-11 に示した。 $d\left(\psi_{1} / 2 \pi\right) d t$, 寸なわちバーの位相の変動周波数は，6 ケ月 周期で 4 cycle/year（沖向き移動）～ 0.5 cycle/year（岸向き 移動）の間で変動している.1000 日以上の変動では, バーの移動速度は 1994 年以前は-1.3〜-0.8 cycle/year（沖 向き移動, 周期 $0.7 \sim 1.25$ 年) で変動していたものの, 1994 年以降, 次第に遅くなり, 1996 年末には-0.1 cycle/year（沖向き移動，周期 10 年）となった. その後, 次第に変動周波数が 1994年以前の值に戻りつつある.

バーの振幅の時間変動を示す $R_{1}$ のスペクトル解析結 果を図-12 に示寸とともに，図-11 と同様に $R_{1}$ の 150 日 以上および 1000 日以上の長周期成分を図-13 を示す． $R_{1}$

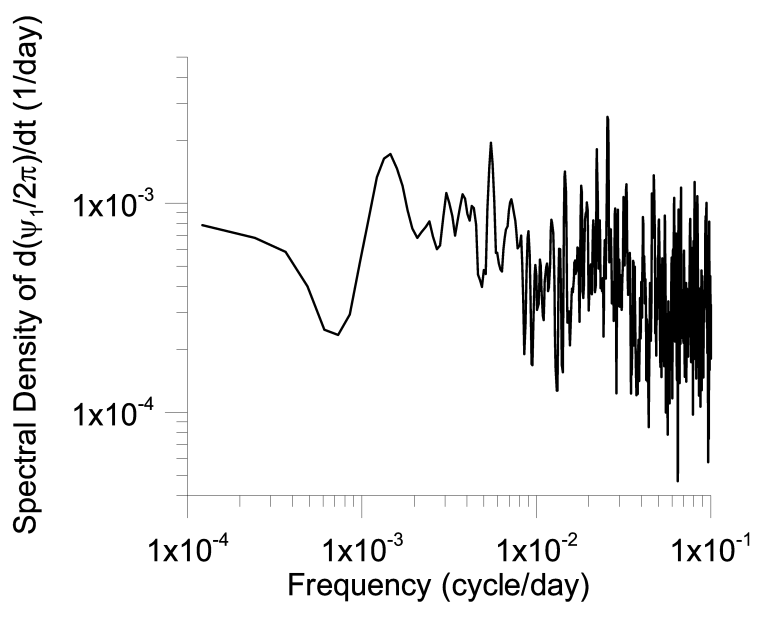

図-10 $d\left(\psi_{1} / 2 \pi\right) / d t$ のスペクトル解析結果

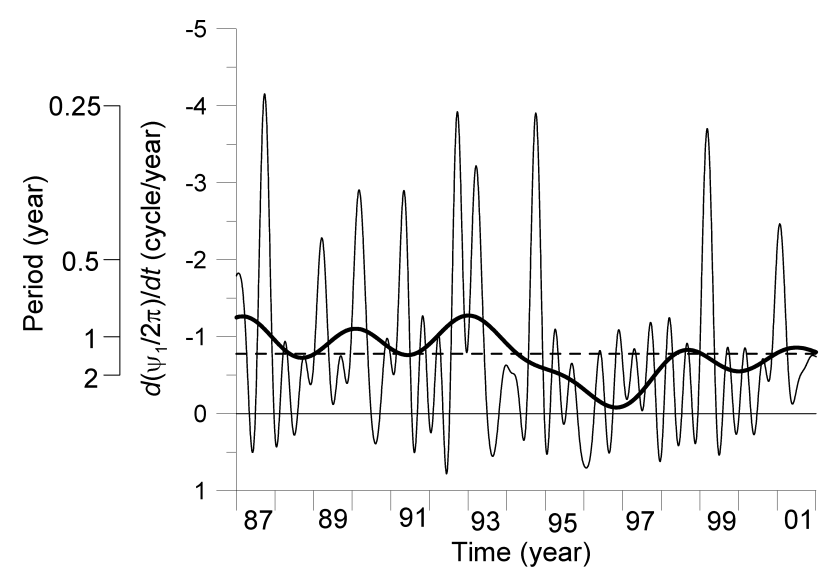

図-11 $d\left(\psi_{1} / 2 \pi\right) / d t$ の長周期成分. 細い実線は 150 日以上の長 周期成分を，太い実線は 1000 日以上の長周期成分を， 破線は全期間の平均を示す. 


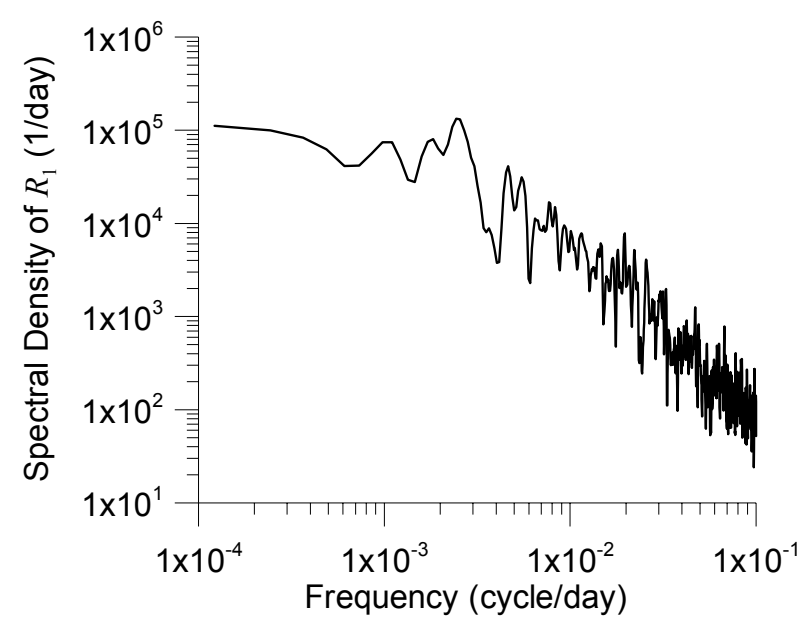

図-12 $R_{1}$ のスペクトル解析結果

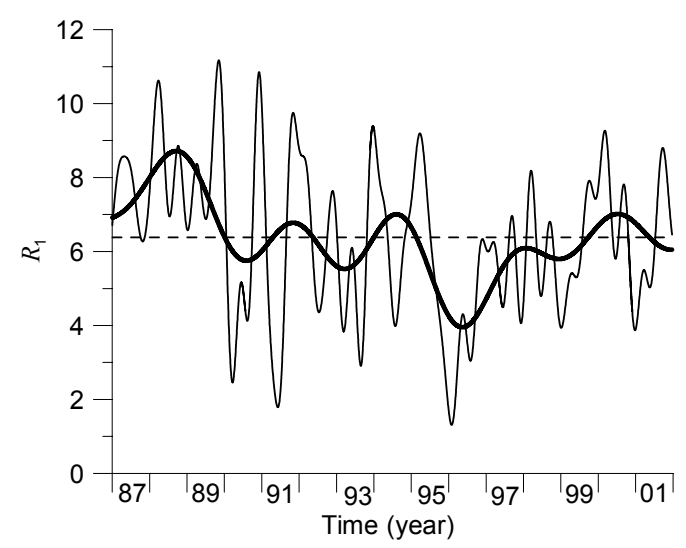

図-13 $R_{1}$ の長周期成分. 細い実線は 150 日以上の長周期成分 を，太い実線は 1000 日以上の長周期成分を，破線は全 期間の平均を示す.

の変動では 400 日（ $f=0.0025$ cycle/day $)$ の周期の変動が 卓越しており， $R_{1}$ は $d\left(\psi_{1} / 2 \pi\right) / d t d$ とは異なった変動特性を 持っているけれども，1000 日以上の長周期変動に注目 してみると， $R_{1}$ も $d\left(\psi_{1} / 2 \pi\right) / d t$ と同様, 解析期間の前半に 比べて後半の方が值が小さく, 特に 1995 年から 1996 年 にかけて小さかった. この結果は， $R_{1}$ の長期変動と $d\left(\psi_{1} / 2 \pi\right) / d t$ のそれとの間に何らかの関連があることを示 唆している.

\section{4. バーの中・長期変動の影響要因}

\section{(1) バーの位相の変動周波数}

バーの沖向き移動には沖波のエネルギーフラックス が影響を与えており，波崎海岸では沖波エネルギーフ ラックスが大きくなるほどバーの沖向き移動が活発で あることが示されている ${ }^{3)}$. また，バーの移動にフィー ドバック機構が関与しているとすればバーの頂部位置
表-1 $d\left(\psi_{1} / 2 \pi\right) / d t$ と各パラメーターとの相関係数

\begin{tabular}{c|c|c}
\hline$\psi_{1}$ & $R_{1}$ & $E_{f}$ \\
\hline 0.01 & -0.21 & -0.16 \\
\hline
\end{tabular}

表-2 $d R_{1} / d t$ と各パラメーターとの相関係数

\begin{tabular}{c|c|c}
\hline$\psi_{1}$ & $R_{1}$ & $E_{f}$ \\
\hline-0.03 & -0.08 & 0.07 \\
\hline
\end{tabular}

や大きさがバーの位相の変動周波数に影響を与える可 能性もある.そこで，バーの位相の変動周波数の変動 原因を検討するために $d\left(\psi_{1} / 2 \pi\right) / d t$ とバ一頂部の位置を示 すパラメーター $\psi_{1}$, バーの振幅の時間変動を示すパラメ 一ター $R_{1}$, および沖波のエネルギーフラックス $E_{f}$ との相 関を調べた。

沖波のエネルギーフラックスは, 以下の式より求め られる。

$$
E_{f}=\frac{1}{16} \rho g\left(H_{1 / 3}\right)_{0}^{2} C_{g 0}
$$

ここで， $\left(H_{13}\right)_{0}$ は沖波有義波高， $C_{\mathrm{g} 0}$ は沖波の群速度であ る. 解析では鹿島港沖の水深約 $23 \mathrm{~m}$ の地点（図-1）で観 測された 2 時間毎の沖波有義波高・周期を用いて計算し たエネルギーフラックスを算術平均して求めた 1 日平均 の沖波エネルギーフラックスを用いた。 なお，長期欠 測期間（1993 年 2 月 7 日～3 月 3 日）の沖波波高 · 周期 は，橋本ら ${ }^{39}$ の波浪推算方法によって求めた值を基にし た.

表-1 は, $d\left(\psi_{1} / 2 \pi\right) / d t$ と各パラメーターとの相関係数を 示したものである. 有意水準 $1 \%$ において，バーの移動 速度はバーの位置とは相関がないけれども，沖波の工 ネルギーフラックスやバーの振幅とは弱い負の相関が ある. バーの移動速度は岸向きを正と定義しているの で，表-1 の結果は沖波エネルギーフラックスおよびバ 一の振幅が大きくなるほどバーの沖向きの移動速度が 大きくなることを示している。

\section{(2) バ一の振幅の変動周波数}

バーの位相の変動周波数と同様に，バーの振幅の変 動周波数（バーの発達速度） $d R_{1} / d t$ と $\psi_{1}, R_{1}, E_{f}$ との相 関係数を求め, 表-2 に示した. 有意水準 $1 \%$ において, バーの振幅の変動周波数はバーの位置とは相関がない けれども，沖波エネルギーフラックスとは弱い正の相 関があり，バーの振幅とは弱い負の相関がある.

バーの振幅の変動周波数にバーの振幅そのものが影 響を与えているという結果は，バーの振幅の変動，す なわちバーの発達にはフィードバック機構が存在して 

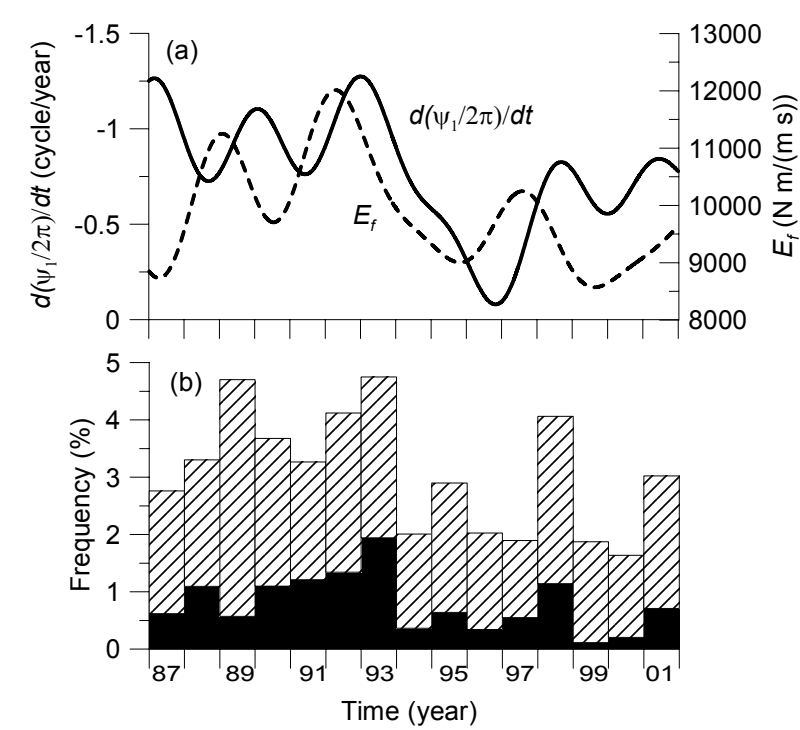

図-14 (a) $d\left(\psi_{1} / 2 \pi\right) / d t$ (実線) と $E_{f}$ (破線) の 1000 日以上の長 周期成分. (b)高波の発生頻度. 黒塗りが $4 \mathrm{~m}$ 以上の波の 発生確率, 斜線が 3 4mの波の発生確率を示す.

いることを示している. 本解析では， $R_{1}$ と $d R_{1} / d t$ との間 には負の相関があることから，バーが発達するとそれ がバーを減衰させる方向に作用し，バーが減衰すると それがバーを発達させる方向に作用するという負のフ イードバック機構が存在していることになる.

\section{5. 考察}

本研究で明らかとなったバーの中・長期変動特性に は栗山 ${ }^{28}$ に示されるような荒天時におけるバーの急激な 移動が影響を及ぼしていると考えられる。しかしなが ら, バーの位相の変動周波数と沖波のエネルギーフラ ックスとの相関がそれほど高くない（表-1）ことからも 推察されるように, 荒天時と言えどもバーが大きく移 動しないことがある. さらに, バーの位相の変動周波 数の 1000 日以上の成分と沖波エネルギーフラックスの 1000 日以上成分や高波の発生確率との比較（図-14）か らも明らかなように，波が大きいときに必ずしもバー の位相の変動周波数が大きくなっているわけではない. 今後は，数值シミュレーションなどを用いてバーの短 期的変動特性およびそれがバーの中・長期変動に与え る影響を検討する必要であると考える.

本研究では, 波崎海岸においてバーの振幅に関して 負のフィードバック機構の存在することが明らかにな ったけれども, Plantら 19ばバーの移動に関して別の二つ のフィードバック機構を示している. その一つは，バ 一頂部で砕波が生ずると沖の砕波位置に向けてバーが 移動し，バーが沖に移動しバー頂部水深が大きくなる
ことによりバー頂部で砕波が生じなくなるとバーの移 動が止まるという負のフィードバック機構（安定のフ イードバック機構）である. しかしながら, 波崎海岸 では，バーの位相の変動周波数はバーの位置とは無関 係であり（表-1），Plant ら 16)が示した負のフィードバッ ク機構は存在していない.もう一つのフィードバック 機構は，正のフィードバック機構（不安定のフィード バック機構）であり，バー頂部で砕波が生じていない とバーが岸に移動し，岸に移動するほじバーの振幅が 減少し, やがて消滅するものである. 波崎海岸では, バーの振幅が小さくなると同じ外力条件であっても発 達しやすくなり, 一方, バーの振幅が大きくなると逆 にバーが減衰しやすくなるため, Plant ら ${ }^{16) か ゙ ス し た よ う ~}$ なフィードバック機構は見出されていない. バー移動 のフィードバック機構に関する以上の違いの原因は現 在のところ不明であり, 今後, 前述したバーの短期変 動特性の検討とあわせた検討が必要であると考える.

\section{6. 結論}

波崎海洋研究施設において 15 年間にわたりほぼ毎日 取得した断面データを経験的複素固有関数法 (CEOF 解 析）などを用いて解析したところ，以下のことが明ら かとなった。

(1) 本解析領域では CEOF 解析のモード 1 で表されてい るバーの周期的沖向き移動が卓越する地形変化であ った. バーの頂部の位置は，モード 1 の複素時間係数 の位相 $\psi_{1}$ と強い相関があった。

(2) $d\left(\psi_{1} / 2 \pi\right) / d t$ で表されるバーの位相の変動周波数の 150 日以上の長周期成分に注目すると，バーの位相の変 動周波数は 6 ケ月周期で 4 cycle/year（沖向き移動） 0.5 cycle/year（岸向き移動）の間で変動していた. 1000 日以上の変動においては，バーの位相の変動周波数 は 1994 年以前は-1.3 〜-0.8 cycle/year（沖向き移動, 周 期 $0.7 \sim 1.25$ 年）の間で変動していたものの，1994 年 以降，次第に遅くなり，1996 年末には-0.1 cycle/year （沖向き移動，周期 10 年）となった. その後，次第 に移動速度が 1994年以前の值に戻りつつある.

バーの振幅の時間変動を表す $R_{1}$ のスペクトルのピ ークは 400 日に存在し, $d\left(\psi_{1} / 2 \pi\right) / d t$ のスペクトルピー クの位置（40 日，180日，700日）とは異なっていた ものの，1000 日以上の長周期変動においては， $R_{1}$ は $d\left(\psi_{1} / 2 \pi\right) / d t$ と同様に観測期間前半よりも後半の方が小 さかった.

(3) バーの位相の変動周波数 $d\left(\psi_{1} / 2 \pi\right) / d t$ およびバーの振幅 の変動周波数 $d R_{1} / d t$ は外力である沖波のエネルギーフ 
ラックスと相関があるとともに，バーの特性の一つ であるバーの振幅とも相関があった.

この結果は，バーの中・長期変動には外力である 沖波のみならずバーの振幅に関する負のフィードバ ック機構（同じ外力条件であっても, バーが発達し ている場合にはバーは減衰しやすく, バーが減衰し ている場合にはバーが発達しやすいメカニズム）が 関与していることを示している.

謝辞 : 4 名の査読者からは非常に有益で建設的なコメン トをいただいた。本研究で使用した沖波データは国土 交通省鹿島港湾・空港整備事務所と当所海象情報研究 室より提供されたものであり，波浪推算データは当所 海洋水理・高潮研究室より提供されたものである.ま た, 本研究で使用した断面データは, 波崎海洋研究施 設に常駐した当所漂砂研究室のメンバーならびに

(株) エコーの観測補助員によって取得されたもので ある.ここに記して謝意を表する.

\section{参考文献}

1) 山本幸次, 佐藤慎司: 大型 2 次元不規則波実験によるバーとバ 一ムの形成過程に関する研究, 海岸工学論文集, 第 45 巻, pp.526-530, 1998 .

2) 日向野純也, 安永義暢: 解放性砂浜域における海底地形変化と 二枚貝の分布形状について, 第 35 回海岸工学講演会論文集, pp.767-771, 1988.

3) 栗山善昭: 沿岸砂州の長期変動特性と底質移動特性, 土木学会 論文集,No.677,pp.115-128,2001.

4) Kuriyama, Y.: Medium-term bar behavior and associated sediment transport at Hasaki, Japan, J. Geophysical Res., Vol. 107, No. C9, 3132, doi:10.1029/2001JC000899,2002.

5) Birkemeier, W. A.: Time scales of nearshore profile changes, Proc. 19th Coastal Eng. Conf., ASCE, pp.1507-1521, 1984.

6) Lippmann, T. C., Holman, R. A. and Hathaway, K. K.: Episodic, nonstationary behavior of a double bar system at Duck, North Carolina, U.S.A., 1986-1991,J. Coastal Res., Special Issue 15, pp.49-75, 1993.

7) Ruessink, B. G. and Kroon, A.: The behaviour of a multiple bar system in the nearshore zone of Terschelling, the Netherlands: 1965-1993, Marine Geology, Vol. 121,pp.187-197, 1994.

8) Wijnberg, K. M. and Terwindt, J. H. J.: Extracting decadal morphological behaviour from high-resolution, long-term bathymetric surveys along the Holland coast using eigen function analysis, Marine Geology, Vol. 126, pp.301-330, 1995.

9) Shand, R. D. and Bailey, D. G.: A review of net offshore bar migration with photographic illustrations from Wanganui, New Zealand, J. Coastal Res., Vol. 15, No.2,pp.365-378, 1999.

10) Rozynski, G.: Data-driven modeling of multiple longshore bars and their interactions, Coastal Eng., Vol.48, pp.151-170, 2003.
11) Shand, R. D., Bailey, D. G. and Shepherd, M. J.: An inter-site comparison of net offshore bar migration characteristics and environmental conditions, $J$. Coastal Res., Vol. 15, pp. 750-765, 1999.

12) Ruessink, B. G., Wijnberg, K. M., Holman, R. A., Kuriyama, Y. and van Enckevort, I. M. J.: Intersite comparison of interannual nearshore bar behavior, J. Geophysical Res., Vol. 108, No. C8, doi:10.1029/ 2002JC001505, 2003.

13) Sallenger, Jr. A. H. and Howd, P. A.: Nearshore bars and the break-point hypothesis, Coastal Eng., Vol. 12, pp.301-313, 1989.

14) Lippmann, T. C. and Holman, R. A.: The spatial and temporal variability of sand bar morphology, J. Geophys. Res., Vol. 95, No. C7, pp.11575-11590, 1990.

15) Plant, N. G., Holman, R. A. and Freilich, M. H.: A simple model for interannual sandbar behavior, J. Geophys. Res., Vol. 104, No. C7, pp.15755-15776, 1999.

16) Plant, N. G., Freilich, M. H. and Holman, R. A.: Role of mophologic feedback in surf zone sandbar response, J. Geophysical Res., Vol. 106, No. C1,pp.973-989, 2001.

17) Larson, M., Capobianco, M. and Hanson, H.: Relation-ship between beach profiles and waves at Duck, North Carolina, determined by canonical correlation analysis, Marine Geology, Vol. 163, pp.275-288, 2000.

18) Greenwood, B. and Osbome, P. D.: Equilibrium slopes and cross-shore velocity asymmetries in a storm-dominated, barred nearshore system, Marine Geology, Vol. 96, pp.211-235, 1991.

19) Miller, H. M., Smith, S. J., Hamilton, D. G. and Resio, D. T.: Cross-shore transport processes during onshore bar migration, Coastal Sediments '99, ASCE, pp.1065-1080, 1999.

20) Elgar, S., Gallagher, E. L. and Guza, R. T.: Nearshore sandbar migration, $J$. Geophysical Res., Vol. 106, No. C6,pp.11623-11627, 2001.

21) 栗山善昭, 山田貴裕, 西守男雄: 沿岸砂州と長周期波との相互 作用に関する現地観測, 海岸工学論文集, 第 48 巻, pp.156-160, 2001.

22) Kuriyama, Y. and Yamada, T.: Influence of low-frequency standing waves on longshore bar development, Proc. 28th Coastal Eng. Conf., ASCE, pp.2926-2935, 2002.

23) Wright, L. D. and Short, A. D.: Morphodynamics variability of surf zones and beaches: a synthesis, Marine Geology, Vol. 56, pp.93-118, 1984.

24) Wright, L. D., Short, A. D. and Green, M. O.: Short-term changes in the morphodynamics states of beaches and surf zones: an empirical predictive model, Marine Geology, Vol. 62, pp.339-364, 1985.

25) 砂村継夫: 海浜地形, 海岸環境工学 (本間 仁監修, 堀川清司 編),pp.130-146, 東京大学出版会, 1985.

26) Larson, M. and Kraus, N. C.: Temporal and spatial scales of beach profile change, Duck, North Carolina, Marine Geology, Vol. 117, pp.75-94, 1994.

27) Sunamura, T. and Takeda, I.: Bar movement and shoreline change: Predictive relations, J. Coastal Res., Special Issue 15, pp.125-140, 1993.

28) 栗山善昭: 沿岸砂州の短期変動特性, 海岸工学論文集, 第 43 巻, pp.576-580, 1996. 
29) Thomton, E. B., Humiston, R. T. and Birkemeier, W.: Bar/trough generation on a natural beach, J. Geophys. Res., Vol. 101, No. C5, pp.12097-12110, 1996.

30) Gallagher, E. 1., Elgar, S. and Guza, R. T.: Observations of sand bar evolution on a natural beach, J. Geophys. Res., Vol. 104, No. C7, pp.32033215, 1998 .

31) Bailard, J. A.: An energetics total load sediment transport model for a planar sloping beach, J. Geophysical Res., Vol. 86, No. C11, pp.10938-10954, 1981.

32) Hoefel, F. and Elgar, S.: Wave-induced sediment transport and sandbar migration, Science, 299, pp.1885-1887, 2003.

33) Liang, G., and Seymour, R.: Complex principal component analysis of wave-like sand motions, Coastal Sediments '91, ASCE, pp.2175-2186, 1991.

34) 横木裕宗, 三村信男, 佐藤圭輔: 主成分分析を用いた大洗港周 辺の海浜地形解析,海岸工学論文集, 第 45 巻,pp.571-575, 1998.

35) 北野利一, 中野 晋, 岡 彰紀, 間瀬 肇: 主成分分析による新
たな地形変動分析法に関する理論的検討, 海岸工学論文集, 第 46巻,pp.626-630, 1999.

36) Ruessink, B. G., van Enckevort, I. M. J., Kingston, K. S. and Davidson, M. A.: Analysis of observed two- and three-dimensional nearshore bar behaviour, Marine Geology, Vol. 169,pp.161-183, 2000.

37) Kuriyama, Y. and Lee, J. H.: Medium-term beach profile change on a bartrough region at Hasaki, Japan, investigated with complex principal component analysis, Coastal Sediments '01, ASCE, pp.959-968, 2001.

38) 内山雄介, 栗山善昭: 仙台湾蒲生干潟前面海浜地形の中期地 形変動に関する複素主成分解析, 土木学会論文集, No.747, pp.135-153, 2003.

39)橋本典明, 川口浩二,真期俊行, 永井紀彦: 第 3 世代波浪推算法 （WAM）の推算精度に関寸る検討, 港湾技術研究所報告, 第 38 巻,第 4 号,pp. 3-47, 1999.

(2005.11.29 受付)

\section{FIELD INVESTIGATION ON LONG-TERM SEAWARD BAR MIGRATION AND ITS CAUSES}

\section{Yoshiaki KURIYAMA, Yoshimasa ITO and Shinichi YANAGISHIMA}

Beach profiles measured once a day for 15 years along the 400-meter-long pier of Hazaki Oceanographical Research Station (HORS) were analyzed with Complex Empirical Orthogonal Function analysis. The duration time of the seaward bar migration ranged from 0.7 to 1.25 years before 1994, whereas it gradually decreased after 1995 and reached 10 years at the end of 1996. The temporal variation of the bar amplitude also had a similar long-term variation, which was large before 1994 and small after 1995. The long-term variation of the cyclic seaward bar migration was caused by the variations of the offshore wave energy flux and by a negative feedback of the bar amplitude. 